\title{
Ultrastructure of a Hyalodiscus species (Bacillariophyceae; Subclass: Coscinodiscophycidae, Fam. Hyalodiscaceae) from brackish waters of Tonga, Oceania
}

\author{
Eugen RotT $^{1}$, Werner Kofler ${ }^{1} \&$ Robert SCHABETSBERGER ${ }^{2}$ \\ ${ }^{1}$ Institute of Botany, LF University of Innsbruck, Sternwartestrasse 15, A-6020 Innsbruck, Austria; corresponding \\ authore-mail: Eugen.rott@uibk.ac.at \\ ${ }^{2}$ Division of Organismal Biology, University of Salzburg, Hellbrunnerstrasse 34, A-5020 Salzburg, Austria
}

\begin{abstract}
A rarely recorded centric diatom of the genus Hyalodiscus was found in three mixed freshwater and brackish environments of Tonga. Both classical morphological and scanning electron microscopic features were used to classify the taxon within currently know taxa from inland and brackwater sites. We recorded stable ultrastructural features (e.g. type of poroids, type and arrangement of rimoportulae) but also several variable morphological features (mainly outline, diameter and structure of the umbilicus and nodulation within the umbilicus centre) as well as variable ultrastructural features (margin of central area; central termination of striae). The loculate nature of puncta closed by rotae and the small fultoportulae potentially typical features for the genus was confirmed. The taxon showed a high similarity to Hyalodiscus lentiginosus JoHN 1982 described from Swan river estuary Australia with the exception of more variable punctation in the central umbilicus area and different variability of central noduli. We also checked for identical features (size, central area) with Hyalodiscus withneyi described by EHRENBERG 1870 from near Great Salt Lake Utah.
\end{abstract}

Key words: centric diatom, epibenthic habitat, loculate poroids with rotae, primitive rimoportulae, umbilicus variability

\section{Introduction}

The genus Hyalodiscus was described from marine deposits in Virginia by EHRENBERG (1845) with the type species Hyalodiscus laevis a centric diatom (diameter $125 \mu \mathrm{m}$ ) with a large hyaline central area. The genus description was supplemented by SEM features by Round et al. 1990. Hyalodiscus was used later as the type genus for the description of the family Hyalodiscaceae (Class Coscinodiscophyceae F.E. Round et R.M. Crawford: subclass Coscinodiscophycidae F.E. Round et R.M. Crawford, Fam. Hyalodiscaceae R.M. Crawford 1990 in Round et al. 1990). Although the highest number of Hyalodiscus species was described from marine environments, early records were also from inland sites, e.g. Hyalodiscus whitneyi from sites (diatomites) near Great Salt Lake in Utah (EHRENBERg 1870). From recent samples, a saline thermal spring pool in Utah, KACZMARSKA \& RUSHFORTH (1983) studied a taxon classified as Hyalodiscus whitney sensu EHRENBERG 1870. The only more recently described Hyalodiscus species from a non-marine (low saline / brackish) habitat is Hyalodiscus lentiginosus JoHN 1982 from two rivers of the Swan river estuary $\mathrm{W}$-Australia, which was recently recorded from a lagoon in Spain (CANTORAL \& ABOAL 2001). The study of the Tonga taxon has the intention to contribute useful information to the ultrastructure of the genus Hyalodiscus rarely studied until now (especially the type of poroids and rimoportulae) and to the knowledge of the biogeography of the brackish species of the genus with special reference to Oceania. Specific attention will be given to aspects originating from the comparative use of LM (phase contrast, bright field) versus SEM for the analysis of the umbilicus.

\section{Materials and methods}

In the context of an expedition through Pacific islands made by the $3^{\text {rd }}$ author with the intention to raise unknown treasures of biodiversity of inland waters, 
plankton and littoral samples were taken also from two Tonga islands (Table 1). Samples from mostly epibenthic (= near bottom) layers in approx. $2 \mathrm{~m}$ depth were collected by diving down with a $30 \mu \mathrm{m}$ mesh plankton net. Twenty-five $\mathrm{ml}$ of water were preserved with $4 \%$ formaldehyde and stained with Rosé Bengal which allowed differentiating the plastids (for details see SchabetSBerger et al. 2009). In the laboratory, the samples were filtered through isopore polycarbonate membrane filters (pore size $1.2 \mu \mathrm{m}$ ) and washed repeatedly with distilled water. The samples were then dried for 48 hours $\left(40{ }^{\circ} \mathrm{C}\right)$, sputter-coated with goldpalladium and examined with a Philips XL20 SEM microscope. LM studies of size variability were made on aqueous samples in sedimentation chambers under the inverted microscope (Reichert Invert). LM details were studied from frustule mounts in the research microscope (Leitz Dialux M20 and Olympus BMX50). For bright field, interference- and phase contrast microscopy (400-, 630- and 1000x) both original samples and washed and dryied materials cleaned with $\mathrm{H}_{2} \mathrm{O}_{2}$ and embedded in Naphrax were used respectively. Black and white pictures were taken with the Olympus camera and a Sony electronic camera with microadapter (Leitz microscope).

Hyalodiscus was found in 3 out of 39 samples taken from various other islands in the S-Pacific in 2004 (SCHABETSBERGER et al. 2009). The richest sample was from a freshwater spring pool influenced by tidal diffusing seawaters (Nioatoua spring pool see Table 1). In this sample the frustules were embedded within an extensive polysaccharide matrix and associated with a minute branched marine red alga and a brown alga. In the two additional samples one from a large, deep, brackish crater lake (Vahi Lahi) and the other from an adjacent lake (Si'i) the centric diatom was associated with several phytoplankton taxa from freshwater environments (e.g. Anabaena sp., Chlamydomonas sp., Chroococcus cf. turgidus, Gyrodinium sp., Quadricoccus cf. ellipticus). In Vai Lahi the sample was dominated by an unknown freshwater dinoflagellate (Peridinium sp.). The presence of freshwater taxa indicates that there must be a strong salinity gradient in the system potentially caused by a freshwater lense positioned on top of the gradually diffusing salt waters.

The specific terminology for Hyalodiscus (mostly adapted from Ross \& Sims 1972, Ross et al. 1979) comprises: (A) Two types of poroids (loculi), a small type extended into a hyaline rim in the proximal (inner) view of the valve and closed by rotae (a specific type of velum closing the areolae with a kind of bar) and a slightly larger type closed by one simple pair of minute lip-like swelling (primitive type of rimoportula). (B) An umbilicus covering the central area of the valve with a slightly umbilicate central swelling on the epivalva, here most frequently hyaline, rarely with a few points (closed loculi?) and with various subcircular thickned areas (appearing sometimes as an additional central subcircular ring around the centre in phase contrast, it seems to be related to variable optical densities of areas with closed loculi). (C) One or up to three thickned but mostly structureless nodular structures (noduli) in the centre of the central area best visible in LM (phase contrast) or lateral SEM.

\section{Results}

\section{Light microscopical features (Figs 1-8)}

In the LM brightfield the large flat discoid frustules appeared as relatively delicately silicified frustules (wall 2-3.5 $\mu \mathrm{m}$ thick), had a slightly widened marginal rim and showed a precisely circular outline in the valve view (Figs 1-3). The valve flat was characterized by a distinct differentiation into a striated marginal area (at the limit of resolution of the LM) and a central non (or little) ornamented hyaline area (Figs 1-5). The radial striation covered a variable part of the diameter but at an average less than $50 \%$ of the diameter. The dense and delicate ornamentation of the marginal area was visible in LM as a rough, non-

Table 1. Site data for the samples taken from Tonga (Pacific).

\begin{tabular}{|c|c|c|c|c|c|c|c|c|}
\hline Site & Island & $\begin{array}{l}\text { Geographic position } \\
\text { Longitude / Latitude }\end{array}$ & $\begin{array}{l}\text { Altitude } \\
\text { (m a.s.l.) }\end{array}$ & $\begin{array}{c}\text { Area } \\
\text { (ha) }\end{array}$ & $\begin{array}{l}\text { Depth } \\
\text { (m) }\end{array}$ & $\begin{array}{l}\text { Temp } \\
\left({ }^{\circ} \mathrm{C}\right)\end{array}$ & pH & $\begin{array}{c}\text { Conductivity } \\
\left(\mu \mathrm{S} \mathbf{c m}^{-1}\right)\end{array}$ \\
\hline Niuatoua & Niuatoputapu & $173^{\circ} 47^{\prime} 52.28^{\prime \prime} \mathrm{W}$ & 2 & $<0.01$ & 1.5 & 27.0 & 6.91 & 2656 \\
\hline spring & & $15^{\circ} 57^{\prime} 22.54 ’ \mathrm{~S}$ & & & & & & \\
\hline \multirow[t]{2}{*}{ Vai Lahi } & Niuafo'ou & $175^{\circ} 37^{\prime} 007.97^{\prime \prime} \mathrm{W}$ & 2 & 1400 & 107 & 29.0 & 8.62 & $>4000$ \\
\hline & & $15^{\circ} 36^{\prime} 05.84^{\prime \prime} \mathrm{S}$ & & & & & & \\
\hline \multirow[t]{2}{*}{ Si'i } & Niuafo'ou & $175^{\circ} 37^{\prime} 03.15^{\prime \prime} \mathrm{W}$ & 0 & 70 & $<10$ & 30.2 & 8.63 & 3642 \\
\hline & & $15^{\circ} 36^{\prime} 05.00^{\prime \prime} \mathrm{S}$ & & & & & & \\
\hline
\end{tabular}


differentiated structure and appeared ornamented by minute irregularly scattered drop-like zones (hyaline areas between striae, e.g. in Fig. 5). In bright field in some cases the striation appeared to be expanded with thinner lines into the valve flat to $2 / 3$ to $3 / 4$ of the radius (Fig. 5) what must be related to the presence of hidden (closed) loculi. The structure of the delimitation zone between the marginal and central area of the valve varied from an almost sharp waving line (Figs 1,2,5) to double circular lines with scattered isolated points on the central ring (Fig. 3) or an irregular densely pointed band with multiple isolated points (Fig. 4) respectively. The sub-circular central area ( $=$ the umbilicus) was often free of striae and puncta but showed variable thinner structures in the center in brightfield, forming one (Fig. 1), two (Figs 2, 5) or up to three slightly elevated (thickened?) areas, which were identified as one (Fig. 7) or up to three (Fig. 8) central noduli in phase contrast. In some valves the central part was ornamented by a rough discoidal ("double-umbilicate"?) structure, but left an unstructured ring open (Figs 1-3) or was ornamented by a few scattered ponts. For some
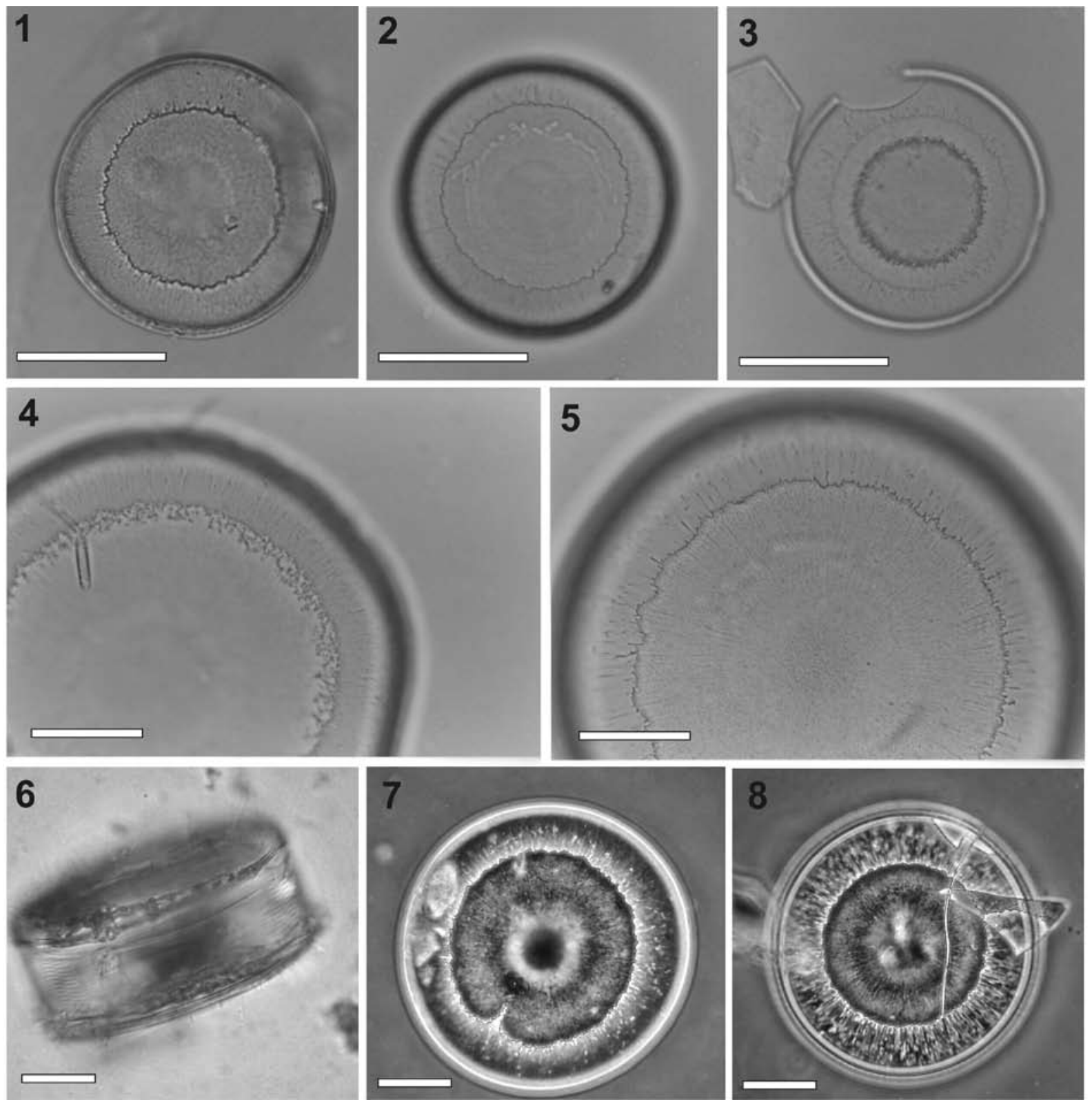

Figs 1-8. Light micrographs of Hyalodiscus sp. from Tonga: $(1-5 ; 7 ; 8)$ valve view; (6) lateral view of cell pair stained with Rose Bengal, inverted microscope; (1-5) show variability of the umbilicus - for details see text; (7-8) phase contrast exhibiting in the valva centre one nodulus in Fig. 7 and three noduli in Fig. 8 respectively. Samples cleaned and mounted in Naphrax except Fig. 6. Scale bars $50 \mu \mathrm{m}$ in $1-3 ; 20 \mu \mathrm{m}$ for all others. 


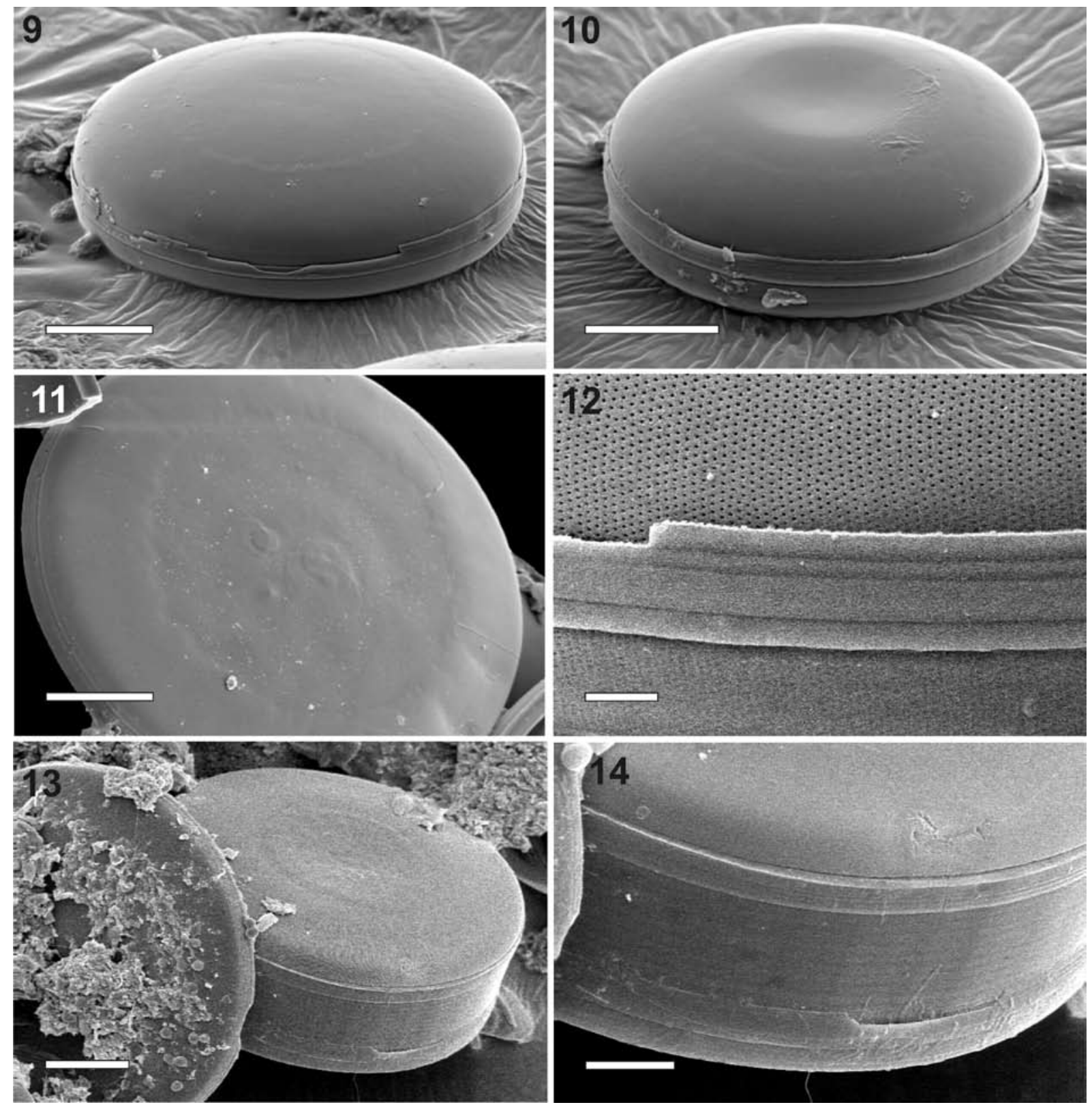

Figs 9-14. Scanning electron micrographs of entire Hyalodiscus frustules: (9) top view of epitheca; (10) view of hypotheca; (11) oblique valve view of an epitheca with three central noduli; (12) detail of Fig. 9.showing the regular lines of areolae on the mantle and parts of copulae; (13-14) lateral view of a cell pair. Scale bars $20 \mu \mathrm{m}$ (Figs 9-11, 13); $2 \mu \mathrm{m}$ (Fig. 12 ), $20 \mu \mathrm{m}$ (Fig. 14).

time (after vegetative division presumably) two lense-shaped (young) cells remained associated in pairs (Fig. 6) forming a cylindrical body hold together by numerous (up to 10) closed copulae (see also Fig. 14). Each cell contained a large number of small discoid plastids of similar size. The cells were often integrated into extended extra-cellular polysaccharide layers (Figs 9, 10).

\section{Scanning electron microscopical features (Figs 9-26)}

The frustules were flat lens- or watchglass-shaped
(Figs 9, 10) with a strictly circular outline and a short pervalvar axis (approx. $30-32 \%$ of the diameter). The central area of the epitheca had a smooth (Fig. 9) or slightly irregularly inflated central part (three noduli in Fig. 11), the hypotheca a slightly depressed centre (Fig. 10). Single cells showed originally a low number $(<5)$ of variable sized closed copulae (Figs 10,12) with one line of equidistant poroids (as partly visible in Fig. 21). We observed a few pairs of cells which were held together by a larger number (up to 10) of simple closed copulae (Figs 13, 14). Near the valve 

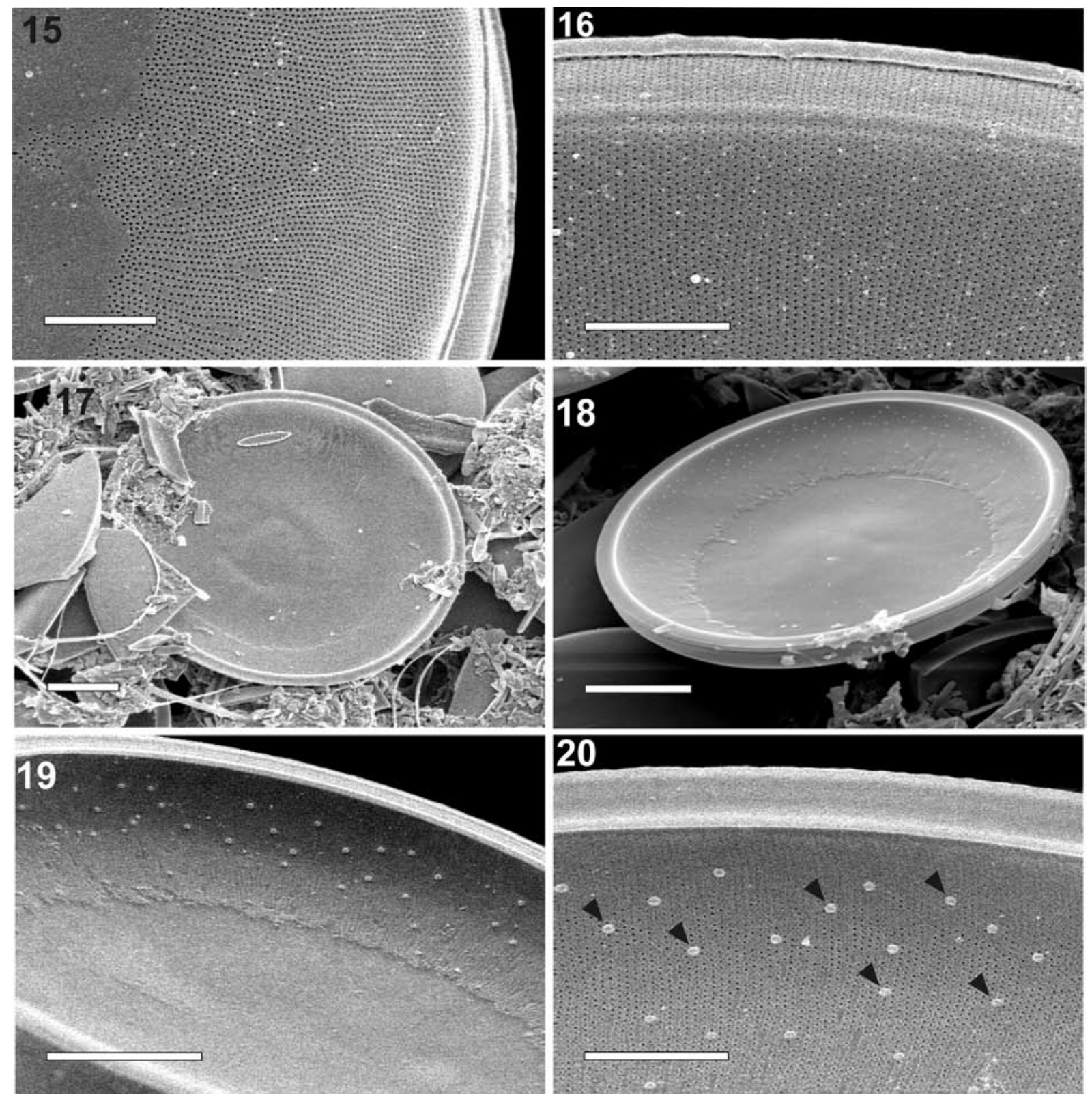

Figs 15-20. Ultrastructural details of Hyalodiscus frustules part 1: (15) radial sector of an epitheca showing regular striae at the mantle becoming gradually irregular toward the centre; (16) detail of regular striation near the mantle. Figs 17-20. Aspects of the interior of the frustule: (17) epitheca with one central nodulus; (18) hypotheca with smooth subcircular central area; (19-20) details of the striated marginal area with scattered rimoportulae (white dots in Fig. 19; examples indicated by black arrows in Fig. 20). Scale bars $5 \mu \mathrm{m}$ (Figs 15, 16, 20); $20 \mu \mathrm{m}$ (Figs. 17, 18); $10 \mu \mathrm{m}$ (Fig. 19).

margin puncta were arranged in regular, dense and strictly radial lines (Figs 12, 15, 16) although not reaching the marginal rim completely. These lines became gradually subradial, irregularly waving or interrupted and less dense toward the centre (Fig. 15 and Table 2). The inside view of the valves showed the central nodulus with a slight variation in thickness (presumably an epitheca in Fig. 17) and the slightly depressed central area from the interior of a hypotheca (Fig. 18). Roughly evenly scattered small, sessile rimoportulae of almost uniform shape and size $(0.15-0.5 \mu \mathrm{m})$ with one simple pair of lips were found in most cases (white dots in Fig. 19, black arrows in Figs. 20, 22- 24) for the interior of the frustules. The interior views (Figs 23, 24) also exhibited an almost uniform size of puncta (areolar poroids) with a somewhat variable hyaline margin closed by simple rotae (see Ross \& Sims 1972, Round et al.1990). The gradual decreasing regularity of the striation towards the centre with hyaline areas in between is documented in Figs 22, 23. From broken valves 

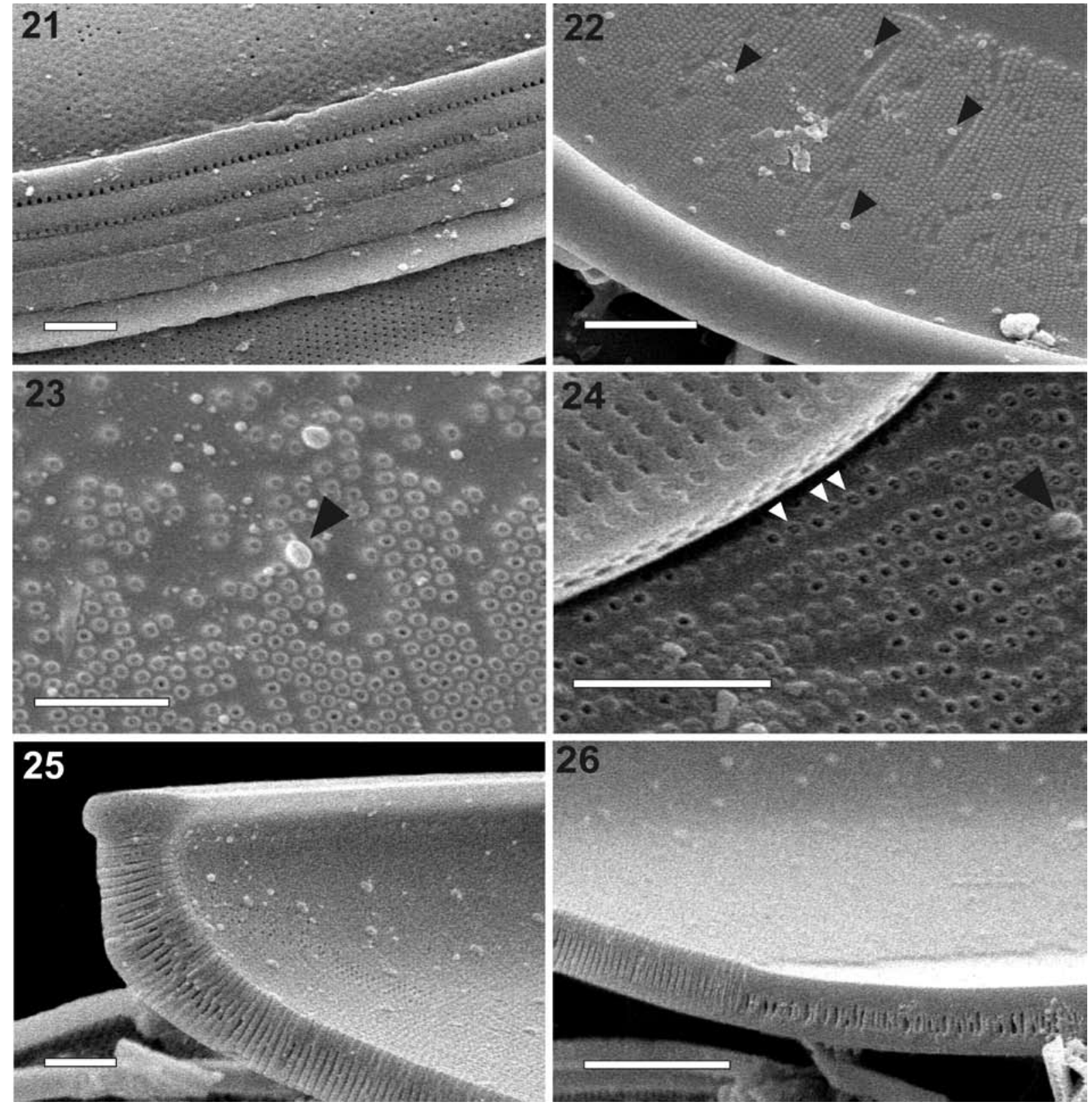

Figs 21-26. Ultrastructural details of Hyalodiscus frustules part 2: (21) Detail of girdle view of a single cell showing 5 overlapping segments (bands) with one regular line of poroids partly visible for the uppermost two bands; (22-24) details of the striations in the valve interior, black arrows indicate rimopotulae; (23) hyaline rim of puncta visible, $(23,24)$ most loculi closed by simple rotae (examples marked by white arrows); $(25,26)$ marginal and central part of a broken valve with open loculi in the striated marginal part (Fig. 25 and left side of Fig. 26) and closed loculi in the central area seen on right side of Fig. 26. Scale bars $2 \mu \mathrm{m}$ (Figs 21, 23, 24, 25); $5 \mu \mathrm{m}$ (Figs 22, 26).

the cross section of the frustule were studied in more detail. The mantle and marginal zone of the valve flat was regularly perforated by tubular structures (loculi) open toward both sides (Fig, 25) but closed by rotae toward the interior (see Figs $23,24)$. From the ending of the marginal striation toward the centre only closed tubular structures (hidden in surface SEM) were found (Fig. 26).

\section{Discussion}

The observed taxon corresponds clearly to Hyalodiscus in its classical (EHRENBERG 1845, HuSTEDT 1930) and modern (Round et al. 1990) definitions. It is a large centric diatom with a defined striated marginal area with uniform striation consisting of loculatae poroids, uniform simple rimoportulae in regular or scattered arrangements. It shows a large hyaline central area (umbilicus) 
of variable dimension with high structural variability (especially concerning diameter and ornamentation). The variability of the number of radial striae and puncta is low near the mantle but highest on the limit between marginal and central area. The genus Hyalodiscus contrast clearly to the more derived genus Coscinodiscus which has two types of rimoportulae instead of one and a more complex structure of loculi (large and small ones). Both more primitive families Hyalodiscaceae and Coscinodiscaceae are differentiated from the more advanced Thalassioraceae by missing of fultoportulae (KACZMARSKA et al. 2006). In spite of the generally different frustule geometry of Hyalodiscus (short pervalvar axis) and Podosira (extended pervalvar axis) ultrastructural similarities are given especially in the type of rimoportulae (labiate processes), but their densities differ considerably (much less dense in Hyalodiscus than Podosira see Round et al. 1990).

On the species levels we found similarities in the ultrastructure (striation, type of rimoportulae, loculi closed with rotae; internal poroids in the central area) with the taxon studied by Round et al. 1990 (on pages 162-163) (it was not possible to find out whether these materials belong to the type species $H$. laevis EHRENBERG 1845 or not). However in contrast to the taxon mentioned above which has a much more spheroid shape and a generally smaller umbilicus the Hyalodiscus from Tonga was strictly lens shaped with a wide umbilicus. Additional differences are found in the rimoportulae arrangement which are concentrated within a marginal ring in the taxon in Round et al. (1990) but dispersed over the whole marginal area in the Tonga material. We can however not share the view of Round et al. 1990 what concerns the internal part of tubular structures related to the puncta: we found no sponge-like (bullulate) structures but regular tubular structures largely identical to loculi which were closed in the interior by rotae (details in Figs. 23, 24 comparable to the ones in Round et al. 1990 Fig. f, page 163). Similar dense loculate structures closed by a massive silica layer cover most of the central area, but were not visible on intact valves in SEM only in the LM brightfield or phase contrast.

The comparison of the Tonga taxon with two taxa from other brackish environments (Table 2) shows general overlapping of valve and umbilicus diameters although the ratio of the umbilicus diameter to valve diameter is lower for $H$. whitneyi from Blue Lake Warm Spring (KazCMARSKa \& RUSHFORTH 1983 a,b). In contrast to the Tonga taxon's variability there is a smaller umbilicus with one pronounced mamilla-like nodulus (Fig. 4 in KACZMASKA \& RushForth 1983 a and Pl. 21 Fig. 2 in Kaczmarska \& RUShForth 1983 b) and a more spherical outline of the valves. The Figs 1011 in KAZCMARSKA \& RUSHFORTH (1983) showed contrasting specimens (from Salt Lake samples of the Diatom Herbarium ANSP Philadelphia) presumably closer related to Ehrenberg's original materials. These have a higher similarity to the Tonga material especially in respect to umbilicus diameter and type of marginal delimitation of the umbilicus. Although we found the highest number of similarities of the Hyalodiscus taxon from Tonga with Hyalodiscus lentiginosus (size, shape, type of loculi and rotae, type and arrangement of rimoportulae) there are remaining differences especially in structures of the umbilicus (variable presence / absence of points in the central area and a variable number of noduli respectively; Table 2) so that we hesitate to name the two taxa identically. In the present situation it seems necessary to step back from describing the Tonga taxon as a new entity (infraspecific taxon?) because we still do not know enough on the variability of ultrastructure features of the few brackish Hyalodiscus species as well a most of the many marine taxa (more than 50 species listed for marine environments in CATAlogue OF Diatom NAMES 2009). It is the matter of future studies to investigate material of $H$. whitneyi from the type locality as well as of other related taxa to solve this question.

\section{Acknowledgements}

We acknowledge Prof. Dr. A. Prasad (Tallahassee) for useful hints to morphological details and references during an earlier phase of the study. Mrs. Theresa Schredelseker is acknowledged for the print setting of the figures.

\section{References}

Cantoral-Uriza, E.A. \& Aboal-SAnjura, M. (2008): Diatomeas (Bacillariophyceae) del marjal OlicaPego (Comunidad Valencia, Espana. - Anales del Jardin Botanico de Madrid 63: 11-128.

Catalogue of Diatom Names (2009): Californian Academy of Sciences. Diatom collection. - http://research. calacademy.org/research/diatoms/ (24.4.09)

EhrenBerg, F. (1870): Über die wachsende Kenntisz des unsichtbaren Lebens als felsbildende Bacillarien in Californien. - Berichte. Königl. Preuss. Akad. Wiss. 1-75. 
Table 2. Morphological features of Hyalodiscus taxa from brackish environments in Tonga from this study (T 1), compared with data from Blue Lake warm spring in Utah / USA in Kaczmarska \& Rushforth (1983a) (T 2) and from Swan River Estuary / Australia in JoHN (1982) (T 3) (abbreviation: $\mathrm{n}=$ number of measurements for T 1; n.a. = no analysis, s.d. $=$ standard deviation).

\begin{tabular}{|c|c|c|c|c|c|}
\hline & & T 1 & & T 2 & T 3 \\
\hline & Range & Mean \pm s.d. & $\mathbf{n}$ & $\begin{array}{c}\text { Range / } \\
\text { Mean }\end{array}$ & Range \\
\hline Valve diameter & $50-129$ & $78.8 \pm 17.0$ & 53 & $65-150$ & $50-150$ \\
\hline Umbilicus diameter & $28-84$ & $50.6 \pm 12.2$ & 38 & $30-63$ & $48-71$ \\
\hline Ratio valve / umbilicus diameter & $1.4-2.0$ & $1.6 \pm 0.2$ & 38 & $1.9-2.3$ & $1.6-2.0$ \\
\hline No. striae $10^{-1} \mu \mathrm{m}$ & $24-45$ & $33.5 \pm 5.5$ & 22 & n.a. & n.a. \\
\hline No. striae marginal & $32-40$ & $36.0 \pm 2.5$ & 12 & 30 & $36-38$ \\
\hline No. striae at umbilicus & $24-35$ & $28.9 \pm 2.2$ & 10 & $28-35$ & $32-33$ \\
\hline No. puncta / $10 \mu \mathrm{m}$ & $28-45$ & $36.0 \pm 5.6$ & 21 & n.a. & n.a. \\
\hline $\begin{array}{l}\text { No. of puncta } \\
\text { at umbilicus }\end{array}$ & $28-42$ & $35.9 \pm 3.6$ & 10 & n.a. & $38-40$ \\
\hline Noduli on umbilicus & $1-3$ & n.a. & 20 & 1 & unclear \\
\hline Hyaline areas between striae & numerous & n.a. & & numerous & numerous \\
\hline Fultoportulae on striae & scattered & n.a. & & none & scattered \\
\hline Puncta on umbilicus & variable & n.a. & & $\begin{array}{c}\text { many small } \\
\text { scattered }\end{array}$ & $\begin{array}{c}\text { in central } \\
\text { area scattered }\end{array}$ \\
\hline
\end{tabular}

EHRENBERG, F. (1845): Neue Untersuchungen über das kleinste Leben als geologisches Moment. - Ber. Bekanntm. Verh. Königl. Preuss. Akad. Wiss. 71: 53-87.

Hustedt, F. (1930): Die Kieselalgen Deutschlands, Österreichs und der Schweiz unter besonderer Berücksichtigung der übrigen Länder Europas sowie der angrenzenden Meeresgebiete. - In: L. Rabenhorst's Kryptogamen-Flora von Deutschland, Österreich und der Schweiz. 7: 290-296.

JoHn, J. (1982): Observations on Hyalodiscus lentiginosus sp. nov. from Western Australia. - Nova Hedwigia 36: 409-421.

Kaczmarska, I. \& Rushforth, S.R. (1983a): Notes on a rare inland Hyalodiscus. - Bacillaria 6: 157-167.

Kaczmarska, I. \& Rushforth, S. R. (1983b): The diatom flora of Blue Lake Warm Springs, Utah, USA. Bibliotheca Diatomologica 2: 1-122.

Kaczmarska, I., Beaton, M., Neoit, A. \& Medlin, L. (2006): Molecular phylogeny of selceted members of the order Thalassiosirales (Bacillariophyta) and evolution of the fultoportulae. - J. Phycol. 42: 121-138.

Ross, R. \& Sims, P.A. (1972): The fine structure of the frustule in centric diatoms: a suggested terminology. British Phycol. J. 7: 139-163.

Ross, R., Cox, E. J., Karayeva, N. I., Mann, D. G., Paddock, T. B. B., Simonsen, R. \& Sims, P.A. (1979): An amended terminology for the siliceous components of the diatom cell. - Nova Hedwigia 64: 513-533.

Round, F.E., Crawford, R.M. \& Mann, D. G. (1990): The diatoms. Biology and morphology of the genera. 747 pp., Cambridge Univ.Pr.

Schabetsberger, R., Drozdowski, G. ,Rott, E., Lenzenweger, R., Jersabek, C., Fiers, F., Traunspurger, W., ReifF, N., Stoch, F. Kotov, A., Martens, K., Schatz, H. \&. KAISER, R. (2009): Losing the bounty? Investigating Species Richness in Isolated Freshwater Ecosystems of Oceania. - Pacific Science 63: 153-179.

(C) Czech Phycological Society

Received April 30, 2009

Accepted June 26, 2009 